\title{
Organic nitrogen in precipitation across Europe
}

\author{
J. N. Cape ${ }^{1}$, Y. S. Tang ${ }^{1}$, J. M. González-Benítez ${ }^{1,2}$, M. Mitošinková ${ }^{3}$, U. Makkonen ${ }^{4}$, M. Jocher ${ }^{5}$, and A. Stolk \\ ${ }^{1}$ Centre for Ecology \& Hydrology, Edinburgh, EH26 0QB, UK \\ ${ }^{2}$ School of Chemistry, University of Edinburgh, EH9 3JJ, UK \\ ${ }^{3}$ Slovak Hydrometeorological Institute, 83315 Bratislava, Slovak Republic \\ ${ }^{4}$ Finnish Meteorological Institute, 00560 Helsinki, Finland \\ ${ }^{5}$ Agroscope Reckenholz-Tänikon ART, 8046 Zürich, Switzerland \\ ${ }^{6}$ National Institute for Public Health and the Environment (RIVM), 3720 BA Bilthoven, The Netherlands
}

Correspondence to: J. N. Cape (jnc@ @eh.ac.uk)

Received: 8 June 2012 - Published in Biogeosciences Discuss.: 5 July 2012

Revised: 9 October 2012 - Accepted: 28 October 2012 - Published: 9 November 2012

\begin{abstract}
Measurements of total nitrogen and inorganic nitrogen in precipitation samples from NitroEurope sites across Europe permit the calculation of organic nitrogen concentrations and wet deposition, by difference. The contribution of organic $\mathrm{N}$ to total $\mathrm{N}$ in precipitation ranged from only a few $\%$ to around $40 \%$ across 18 sites from northern Finland to Italy, similar to results from previous individual studies. This paper presents the absolute and relative contributions of organic $\mathrm{N}$ to wet $\mathrm{N}$ deposition across Europe, and examines seasonal trends. There were only weak correlations with other solutes in precipitation. These simple statistics indicate that sources of organic $\mathrm{N}$ in precipitation vary across Europe, and that no single source is responsible. The organic $\mathrm{N}$ contributes to total $\mathrm{N}$ deposition, yet this input is rarely quantified in nitrogen budgets.
\end{abstract}

\section{Introduction}

The effects of nitrogen $(\mathrm{N})$ deposition on ecosystems are often expressed in terms of the wet deposition of inorganic nitrogen, as ammonium $\left(\mathrm{NH}_{4}^{+}\right)$and nitrate $\left(\mathrm{NO}_{3}^{-}\right)$ions in precipitation. Sometimes, the additional dry deposition of nitrogen-containing gases and particles is included in the deposition estimate, but rarely is the contribution of organic nitrogen $(\mathrm{ON})$ included. This is partly because of the difficulty in characterising the various individual components of $\mathrm{ON}$, even the water-soluble organic nitrogen (WSON) in precipitation. However, the significant contribution of WSON to wet $\mathrm{N}$ deposition is now beyond doubt, given the many measurements from around the world (Cornell, 2011; Cornell et al., 2003; Neff et al., 2002). Although WSON is usually estimated from the difference between the total $\mathrm{N}$ content of precipitation and the inorganic $\mathrm{N}$, a process which can lead to large uncertainties, some data are also available on the role of individual compounds or groups of compounds, such as urea, amines or amino-acids, but these generally only contribute a small proportion of the WSON. Some WSON is associated with large macromolecules, or humic-like substances (Kieber et al., 2005). The lack of data on the chemical form of WSON has greatly hampered attempts at identifying sources, and therefore the possibility of controls on emissions, many of which are likely to be of biological origin (Cape et al., 2011). Nevertheless, the observation that, on average, WSON contributes around $30 \%$ of total wet-deposited $\mathrm{N}$ (Cornell, 2011) means that its role should not be ignored when attempting to quantify the deposition of $\mathrm{N}$.

In this paper we present the results of measurements of total water-soluble nitrogen in rain samples from sites across Europe, which when combined with data on the inorganic components (ammonium and nitrate) allow the estimation of the water-soluble organic nitrogen content of precipitation. The data are discussed in terms of spatial and temporal variation, and in comparison with the inorganic nitrogen composition. 


\section{Methods}

This study was part of the EU Framework Programme 6 Integrated Project "NitroEurope" (www.nitroeurope.eu). Wet deposition of $\mathrm{N}$ was measured at a network of "Level 1" sites across Europe, and originally only the inorganic ions $\left(\mathrm{NH}_{4}^{+}\right.$ and $\mathrm{NO}_{3}^{-}$) were measured. At "Level 1" sites the concentrations of nitrogen compounds in air and precipitation were measured using time-averaged methods, to provide a basic understanding of the spatial and temporal patterns of reactive $\mathrm{N}$ in the atmosphere over Europe, and to permit the estimation of wet and dry deposition, the latter using inferential methods (Flechard et al., 2011; Tang et al., 2009). These sites can be described as "rural", and were chosen to provide a regionally representative estimate of air composition. At "Level 3" sites more detailed measurements were made, usually at higher time resolution, and with the use of wetonly samplers rather than bulk samplers for measuring wet deposition (Skiba et al., 2009), but not all the "Level 3" sites participated in this study.

Inclusion of a measurement of total $\mathrm{N}$ concentration in precipitation samples, combined with the measured inorganic ion concentrations, permitted an estimate to be made of the WSON, and its contribution to the total wet deposition of N. Moreover, several other research groups who were part of NitroEurope, but not involved in "Level 1" activities, agreed to participate, bringing the total number of sites up to over 20. Several of these sites proved to have consistent problems with loss of samples from contamination, and have not been used here, but 18 sites (Table 1) provided sufficient valid samples for analysis. The opportunistic nature of this approach, relying on a single central laboratory for total $\mathrm{N}$ analysis, led to some additional uncertainties in the final data, as explained below. However, without these measurements, the quantification of wet $\mathrm{N}$ deposition across Europe would have been systematically underestimated.

\subsection{Main network}

As part of the NitroEurope IP wet deposition was measured at the primary network sites (Level 1) across Europe (Flechard et al., 2011). The network comprised bulk Rotenkamp samplers (Dämmgen et al., 2005); each unit consisted of two samplers (to provide replicate samples) mounted $1.5 \mathrm{~m}$ above ground, or in the case of forest sites, above the canopy. Samples were taken monthly, and sent to a central laboratory for analysis (Slovak Hydrometeorological Institute, Bratislava, Slovak Republic). Samples were protected during and after sampling by the addition of the biocide thymol (2-isopropyl-5-methylphenol). Major inorganic ion composition was measured using ion chromatography (IC) (Dionex 3000, with column CS12A for cations: $\mathrm{NH}_{4}^{+}, \mathrm{Na}^{+}, \mathrm{K}^{+}, \mathrm{Ca}^{2+}, \mathrm{Mg}^{2+}$ and AS4A-SC for anions: $\mathrm{SO}_{4}^{2-}, \mathrm{NO}_{3}^{-}, \mathrm{Cl}^{-}, \mathrm{PO}_{4}^{3-}$ ). In addition $\mathrm{pH}$ and conductivity were measured. At the time of ion analysis, two $2 \mathrm{ml}$ filtered $(0.45 \mu \mathrm{m})$ subsamples were taken into vials prepared with additional thymol $(200 \mu \mathrm{g})$ and shipped to the laboratory at $\mathrm{CEH}$, where they were analysed for total $\mathrm{N}$ using high-temperature chemiluminescence in flow injection mode (ANTEK $8060 \mathrm{M}$ ). Triplicate $20 \mu \mathrm{l}$ injections were made into a flow of $10 \%$ methanol in water, and multi-point calibrations were made using both $\left(\mathrm{NH}_{4}\right)_{2} \mathrm{SO}_{4}$ and $\mathrm{NaNO}_{3}$ to ensure correct operation of the detector (both salts should give identical responses). The method provides linear equimolar response to all but a few $\mathrm{N}$-containing compounds, both inorganic and organic, the exceptions being molecules containing $\mathrm{a}-\mathrm{C} \equiv \mathrm{N}$ bond or some heterocyclic compounds. The detection limit for total $\mathrm{N}$ was $1 \mu \mathrm{M}$. Reproducibility of triplicate analyses was better than $1 \%$.

Inorganic ion concentrations determined by IC were then subtracted from the total $\mathrm{N}$ concentrations to obtain the "organic N" concentrations, referred to as "water soluble organic N" (WSON). This process inevitably leads to increased uncertainties, and occasional (small) negative values which are retained in the statistical analysis. Contaminated samples, as evidenced by high potassium and/or phosphate concentrations (from bird excreta), and samples where the calculated WSON concentration was large and negative (i.e. calculated negative WSON was more than $20 \%$ of the measured total $\mathrm{N}$, see discussion below for possible reasons for this) were excluded from the analysis.

For quality control, analytical standards (CRM - certified reference material) from the Slovak lab were sent to CEH for analysis as samples; agreement was within the combined uncertainties of the two laboratories. The Slovak laboratory also participates once annually in the EMEP "round robin" for rain water samples on major inorganic anions and cations, $\mathrm{pH}$, conductivity and heavy metals, and twice annually in the GAW WMO Laboratory Intercomparison Study (LIS) for rain water samples on major inorganic anions and cations, $\mathrm{pH}$ and conductivity as an accredited EMEP laboratory.

A list of the sites from the main NitroEurope network is given in Table 1. Only sites with at least one year of valid data have been used. At some sites contamination was too frequent to permit construction of a valid data set.

\subsection{Other data sources}

Other research groups in the NitroEurope IP have been making their own measurements of rainfall composition as part of ongoing projects. Although several different methods have been employed, a similar "opportunistic" approach was taken to estimate WSON. Empty sample vials, treated with thymol, were sent from CEH to each of the participating laboratories, and subsamples taken at the time of inorganic analysis, then sent back to CEH for analysis of total N. The inorganic N measurement data from these laboratories were then used to calculate WSON from the measured total $\mathrm{N}$ for each sample. 
Table 1. List of sites with locations; those in the NitroEurope Level 1 network (Flechard et al., 2011) are shown by ${ }^{\mathrm{a}}$, and in the NitroEurope Level 3 network by ${ }^{b}$ (http://www.nitroeurope.eu/sites_data_page).

\begin{tabular}{llrrl}
\hline Name & Country & Latitude & Longitude & Sampler type/frequency \\
\hline Pallas & Finland & 68.00 & 24.24 & bulk/1 week \\
Virolahti & Finland & 60.52 & 27.64 & bulk/1 week \\
Polwet $^{\mathrm{a}}$ & Poland & 52.76 & 16.31 & bulk/1 month \\
Hainich $^{\mathrm{a}}$ & Germany & 51.08 & 10.45 & bulk/1 month \\
Grillenburg $^{\mathrm{a}}$ & Germany & 50.95 & 13.51 & bulk/1 month \\
Wetzstein $^{\mathrm{a}}$ & Germany & 50.45 & 11.46 & bulk/1 month \\
Vielsalm $^{\mathrm{a}}$ & Belgium & 50.31 & 6.00 & bulk/1 month \\
Oensingen $^{\mathrm{b}}$ & Switzerland & 47.17 & 7.44 & wet-only/1-2 week \\
Lägeren $^{\mathrm{a}}$ & Switzerland & 47.48 & 8.37 & bulk/1 month \\
Fontainebleau $^{\mathrm{a}}$ & France & 48.48 & 2.78 & bulk/1 month \\
Puéchabon $^{\mathrm{a}}$ & France & 43.74 & 3.60 & bulk/1 month \\
Le Bray $^{\mathrm{a}}$ & France & 44.72 & -0.77 & bulk/1 month \\
San Rossore $^{\mathrm{a}}$ & Italy & 43.73 & 10.28 & bulk/1 month \\
Roccarespampani & Italy & 42.46 & 11.93 & bulk/1 month \\
Rotterdam & Netherlands & 51.95 & 4.43 & wet-only/2 week \\
Speulderveld $_{\text {Vredepeel }}$ & Netherlands & 52.26 & 5.71 & wet-only/2 week \\
Wieringerwerf $^{\text {Nieringer }}$ & Netherlands & 51.57 & 5.86 & wet-only/2 week \\
\hline
\end{tabular}

Table 2a. Average precipitation composition across all sites (precipitation weighted mean concentrations in $\mathrm{mg} \mathrm{N} 1^{-1}$ ).

\begin{tabular}{lccrrrrr}
\hline Site & Start & End & $\begin{array}{r}\text { Period } \\
\text { yr }\end{array}$ & $\begin{array}{r}\mathrm{Precipn}_{\mathrm{mm} \mathrm{yr}^{-1}} \\
\mathrm{mg} \mathrm{N}^{-1}\end{array}$ & $\begin{array}{r}\mathrm{NH}_{4}^{+} \\
\mathrm{mg} \mathrm{N}^{-1}\end{array}$ & $\begin{array}{r}\mathrm{WSON}^{-1} \\
\mathrm{mg} \mathrm{N}^{-1}\end{array}$ \\
\hline Pallas & $05 / 09$ & $12 / 09$ & 0.58 & 512 & 0.07 & 0.11 & 0.10 \\
Virolahti & $05 / 09$ & $12 / 09$ & 0.59 & 703 & 0.16 & 0.22 & 0.09 \\
Oensingen & $08 / 06$ & $12 / 08$ & 2.32 & 984 & 0.42 & 0.20 & 0.12 \\
Fontainebleau & $01 / 08$ & $01 / 11$ & 2.94 & 634 & 0.13 & 0.11 & 0.15 \\
Grillenburg & $01 / 08$ & $12 / 10$ & 2.91 & 830 & 0.42 & 0.46 & 0.10 \\
San Rossore & $03 / 08$ & $12 / 10$ & 2.75 & 939 & 0.12 & 0.29 & 0.03 \\
Roccarespampani & $05 / 08$ & $01 / 11$ & 2.58 & 835 & 0.11 & 0.11 & 0.09 \\
Puéchabon & $02 / 08$ & $01 / 11$ & 2.66 & 705 & 0.34 & 0.45 & 0.05 \\
Polwet & $01 / 08$ & $02 / 11$ & 2.93 & 574 & 0.38 & 0.40 & 0.13 \\
Le Bray & $02 / 08$ & $01 / 09$ & 0.93 & 801 & 0.28 & 0.45 & 0.03 \\
Lägeren & $02 / 08$ & $01 / 11$ & 2.76 & 980 & 0.46 & 0.26 & 0.18 \\
Hainich & $03 / 08$ & $01 / 11$ & 2.74 & 748 & 0.35 & 0.45 & 0.08 \\
Wetzstein & $02 / 08$ & $01 / 11$ & 2.90 & 807 & 0.47 & 0.50 & 0.03 \\
Vielsalm & $01 / 08$ & $02 / 09$ & 1.07 & 1354 & 0.24 & 0.19 & 0.10 \\
Rotterdam & $09 / 08$ & $12 / 11$ & 3.22 & 864 & 0.57 & 0.33 & 0.05 \\
Vredepeel & $09 / 08$ & $12 / 11$ & 3.26 & 621 & 0.99 & 0.34 & 0.11 \\
Wieringerwerf & $09 / 08$ & $12 / 11$ & 3.26 & 630 & 0.60 & 0.36 & 0.02 \\
Speulderveld & $09 / 08$ & $12 / 11$ & 3.26 & 914 & 0.71 & 0.35 & 0.03 \\
\hline
\end{tabular}

\section{Results}

\subsection{Concentrations and deposition}

The average data for all sites is shown in Table 2, together with the period over which they provided samples for WSON analysis, and the \% data capture expressed in terms of the proportion of rainfall sampled (i.e. excluding periods when samples were contaminated, or data were missing). Average concentration data are expressed as the precipitation-weighted mean over the period; annual deposition data show the product of the precipitation-weighted mean concentration and the calculated annual precipitation (total sample volume/sampling period in years). The precipitation volume of excluded samples was included in calculating annual precipitation.

Average concentrations of total water-soluble $\mathrm{N}$ ranged from $0.3 \mathrm{mg} \mathrm{N}^{-1}$ in northern Finland to $1.5 \mathrm{mg} \mathrm{Nl}^{-1}$ in the Netherlands, while annual wet deposition ranged from 
Table 2b. Average wet deposition of $\mathrm{N}\left(\mathrm{kg} \mathrm{N} \mathrm{ha}^{-1} \mathrm{yr}^{-1}\right)$ at all sites, from data in Table 2a.

\begin{tabular}{lrrrrrr}
\hline Site & $\mathrm{NH}_{4}-\mathrm{N}$ & $\mathrm{NO}_{3}-\mathrm{N}$ & WSON & Total N & $\begin{array}{r}\text { WSON } \\
\% \text { total }\end{array}$ & $\begin{array}{r}\% \text { mm } \\
\text { sampled }\end{array}$ \\
\hline Pallas & 0.34 & 0.58 & 0.51 & 1.42 & $36 \%$ & 100 \\
Virolahti & 1.10 & 1.52 & 0.64 & 3.25 & $20 \%$ & 96 \\
Oensingen & 4.09 & 1.94 & 1.21 & 7.24 & $17 \%$ & 85 \\
Fontainebleau & 0.80 & 0.72 & 0.93 & 2.45 & $38 \%$ & 100 \\
Grillenburg & 3.52 & 3.84 & 0.79 & 8.15 & $10 \%$ & 85 \\
San Rossore & 1.14 & 2.70 & 0.30 & 4.15 & $7 \%$ & 66 \\
Roccarespampani & 0.90 & 0.90 & 0.73 & 2.53 & $29 \%$ & 82 \\
Puéchabon & 2.42 & 3.20 & 0.34 & 5.96 & $6 \%$ & 68 \\
Polwet & 2.17 & 2.27 & 0.72 & 5.16 & $14 \%$ & 97 \\
Le Bray & 2.22 & 3.61 & 0.28 & 6.11 & $5 \%$ & 71 \\
Lägeren & 4.48 & 2.51 & 1.74 & 8.73 & $20 \%$ & 81 \\
Hainich & 2.58 & 3.39 & 0.56 & 6.53 & $9 \%$ & 86 \\
Wetzstein & 3.80 & 4.01 & 0.25 & 8.05 & $3 \%$ & 98 \\
Vielsalm & 3.26 & 2.51 & 1.35 & 7.12 & $19 \%$ & 74 \\
Rotterdam & 4.89 & 2.83 & 0.45 & 8.17 & $6 \% *$ & 94 \\
Vredepeel & 6.17 & 2.13 & 0.67 & 8.98 & $7 \% *$ & 95 \\
Wieringerwerf & 3.79 & 2.29 & 0.15 & 6.23 & $2 \% *$ & 96 \\
Speulderveld & 6.52 & 3.20 & 0.24 & 9.96 & $2 \% *$ & 99 \\
\hline
\end{tabular}

* Possibly underestimated, because colorimetric method used for $\mathrm{NH}_{4}^{+}-\mathrm{N}$.

$1.4 \mathrm{~kg} \mathrm{Nha}^{-1}$ to $10 \mathrm{~kg} \mathrm{Nha}^{-1}$. The proportion of WSON was from $2 \%$ in the Netherlands to $38 \%$ at Fontainebleau, France. Precipitation-weighted average concentrations of inorganic $\mathrm{N}\left(\mathrm{NH}_{4}^{+}\right.$and $\left.\mathrm{NO}_{3}^{-}\right)$can be compared with wet-only concentrations of inorganic $\mathrm{N}$ from the EMEP monitoring network (Hjellbrekke and Fjaeraa, 2011) for 2009 in Fig. 1. The sites used in this study cover the range of rain composition observed across Europe. Annual average deposition of ammonium and nitrate was highly correlated across all sites excluding the Netherlands $\left(r^{2}=0.42, n=15\right)$, whereas the Dutch samples showed a much greater contribution from ammonium. Across all sites, the deposition of WSON was not correlated with reduced, oxidised or total $\mathrm{N}$ deposition, but the proportion of WSON was significantly $(P<0.001)$ negatively correlated with total wet $\mathrm{N}$ deposition (Fig. 2). Orthogonal regression across all the sites gave (uncertainty in parameters is s.e. of estimate)

WSON $\% \mathrm{TN}=33( \pm 5)-3.2( \pm 0.8)$

$$
\times \text { wet dep N/kg ha }{ }^{-1} \mathrm{yr}^{-1} ; r^{2}=0.51 \text {. }
$$

The inverse relationship with wet deposited nitrate (Fig. 3) was

$$
\begin{aligned}
\text { WSON\%TN } & =36( \pm 4)-9.2( \pm 1.5) \\
& \times \text { wet dep } \mathrm{NO}_{3}-\mathrm{N} / \mathrm{kg} \mathrm{ha}^{-1} \mathrm{yr}^{-1} ; r^{2}=0.71
\end{aligned}
$$

and was much stronger than for ammonium (data not shown):

WSON $\% \mathrm{TN}=25( \pm 4)-3.7(1.2)$

$$
\times \text { wet dep } \mathrm{NH}_{4}-\mathrm{N} / \mathrm{kg} \mathrm{ha}^{-1} \mathrm{yr}^{-1} ; r^{2}=0.38 \text {.(3) }
$$

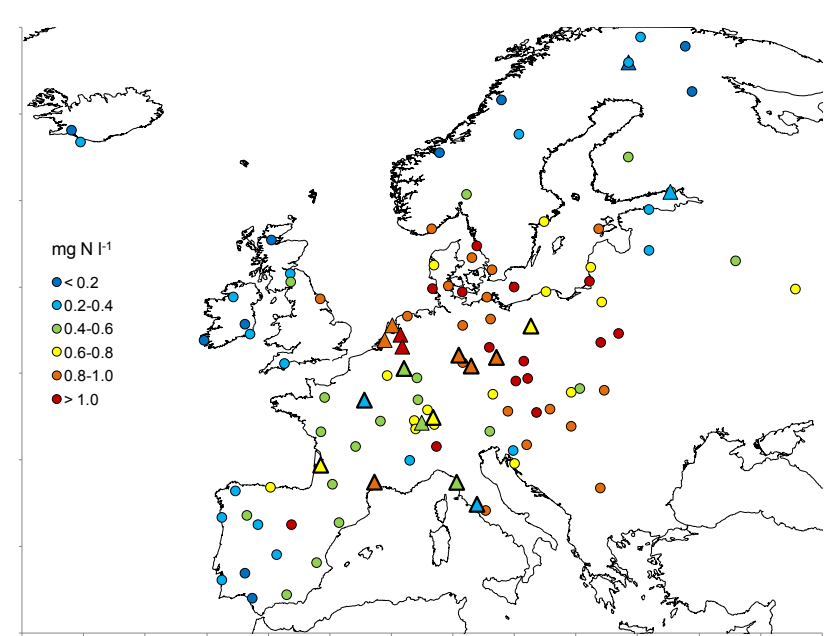

Fig. 1. Annual rainfall-weighted average concentrations $\left(\mathrm{mg} \mathrm{N}^{-1}\right)$ of inorganic $\mathrm{N}\left(\mathrm{NH}_{4}^{+}\right.$and $\left.\mathrm{NO}_{3}^{-}\right)$in precipitation across Europe. The circles show colour-coded concentrations from the EMEP monitoring sites for 2009 (http://ebas.nilu.no/), and the triangles show the data from this study for comparison (see Table 1 for details). "Level 1 " sites are shown with bold outline.

\subsection{Seasonal patterns}

Seasonality in each data series was measured by fitting a sine curve through the monthly data using non-linear regression in SigmaPlot,v10 (Systat Software Inc.). Significant seasonal patterns in concentration of ammonium and nitrate were observed at approximately half of the sites (Table 3), with a 


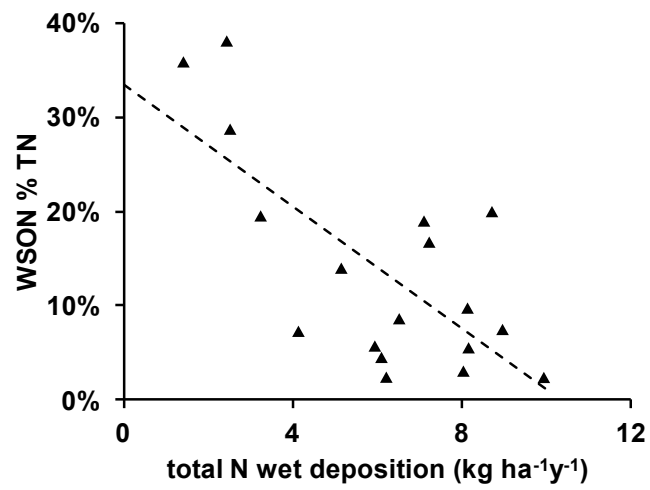

Fig. 2. Relationship between the proportion of total $\mathrm{N}$ represented by WSON, and the wet deposition of total $\mathrm{N}$ at each site, showing the strong inverse relationship.

spring maximum between February and May (e.g. Fig. 4). At some sites there was a seasonal pattern in deposition, with a peak slightly later in the year (data not shown), but at no site was there a statistically significant seasonal pattern in either the concentration or deposition of WSON. Although this is a crude measure of seasonality, it is the simplest indicator for such a short data set, and does show the lack of seasonal patterns in all components at the more southerly sites compared with central Europe; the two Finnish sites had no data from the winter period.

\subsection{Correlations in space and time}

Despite the lack of correlation across sites for annual-average data (Sect. 3.1), WSON concentrations and/or deposition were correlated in time with inorganic $\mathrm{N}$ at some individual sites. Given the strong inverse dependence of concentrations on precipitation amounts (small amounts tend to have high concentrations), within-site correlations were analysed using deposition data $\left(\mathrm{mg} \mathrm{N} \mathrm{m}^{-2} \mathrm{month}^{-1}\right)$ rather than concentration data, and Spearman's rank correlation coefficient to test for significant correlations over time within a site. There were no statistically significant correlations at most sites, but WSON deposition was significantly negatively correlated with both $\mathrm{NH}_{4}^{+}$and $\mathrm{NO}_{3}^{-}$at San Rossore and at Vielsalm, and significantly positively correlated with $\mathrm{NH}_{4}^{+}$(only) at Lägeren, and with both $\mathrm{NH}_{4}^{+}$and $\mathrm{NO}_{3}^{-}$at Pallas (Table 4). No clear spatial pattern in correlations emerged over Europe.

\section{Discussion}

\subsection{Uncertainties}

With this type of project, involving sub-sampling and analysis in two different laboratories, the possibility of artefacts is increased, with increases in the uncertainty associated with the results. Typical uncertainties in calculating individual

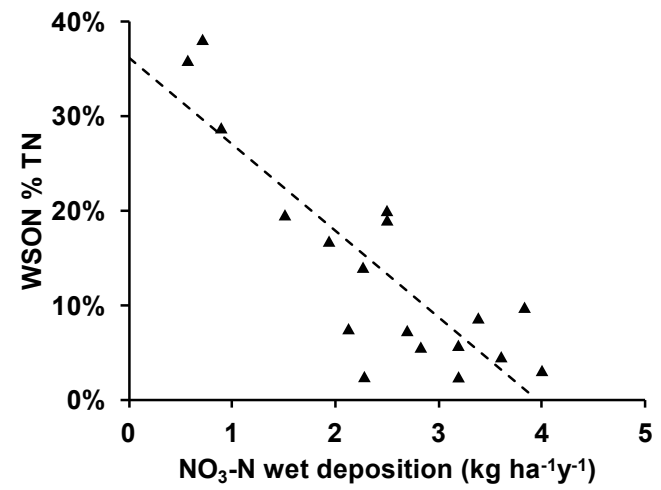

Fig. 3. As for Fig. 2, but showing WSON as $\%$ of total $\mathrm{N}$ in terms of wet deposition of $\mathrm{NO}_{3}-\mathrm{N}$ at each site.

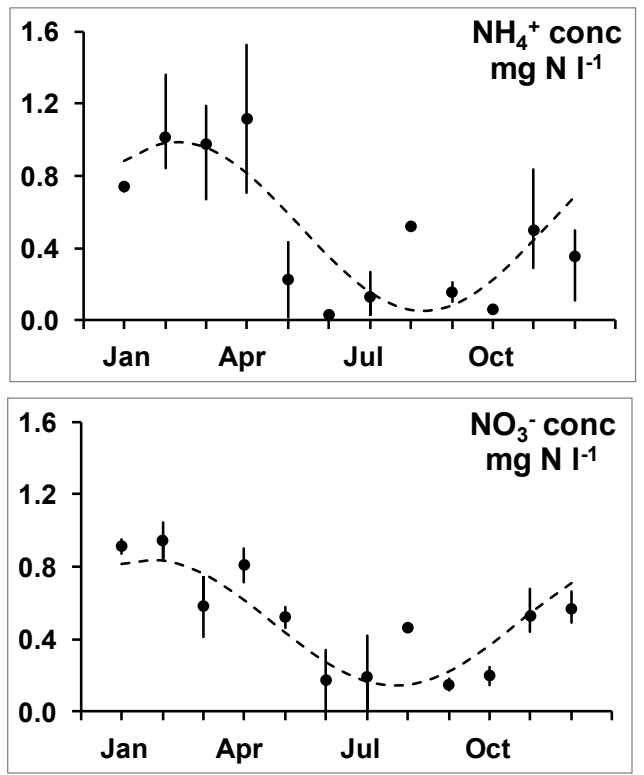

Fig. 4. Seasonal variation in concentrations of inorganic ions at Grillenburg. Points show monthly mean data, and bars show ranges. The parameters of the fitted sine function are shown in Table 3.

WSON concentrations are $0.08 \mathrm{mg} \mathrm{N}^{-1}$, and small, apparently negative, concentrations have been included in the above calculations to avoid the bias caused by ignoring (or treating as zero) the small negative values which arise as a result of uncertainties in the total $\mathrm{N}$ and inorganic $\mathrm{N}$ concentrations (Cornell and Jickells, 1999). However, on some occasions the measured total $\mathrm{N}$ at $\mathrm{CEH}$ was significantly less than the sum of the $\mathrm{NH}_{4}^{+}$and $\mathrm{NO}_{3}^{-}$concentrations reported by the originating laboratory, implying artefacts during the sub-sampling process, and/or systematic differences in calibrations between the laboratories. The latter possibility was checked by the analysis of analytical standards, shipped from the Slovak laboratory to CEH. No bias could be detected, implying no systematic 
Table 3. Seasonal variations in ammonium and nitrate concentrations $\left(\mathrm{mg} \mathrm{N}^{-1}\right)$ from non-linear fitting of a sine function to monthly data, where $C(m)=C_{0}+A \cdot \sin \left(\pi / 6 .\left(m-m_{0}+3\right)\right)$, and $C_{0}, A$ and $m_{0}$ are fitted parameters for the annual mean, seasonal amplitude and month of maximum amplitude, respectively. Data are shown only for sites where the probability of $A>0$ exceeds $95 \%$. Standard errors of fitted parameters are shown in parentheses.

\begin{tabular}{|c|c|c|c|c|c|c|c|c|c|c|c|c|}
\hline \multirow{2}{*}{$\begin{array}{l}\text { Site } \\
\text { Pallas }\end{array}$} & \multicolumn{2}{|l|}{$\begin{array}{r}\mathrm{NH}_{4}^{+} \\
\mathrm{C}_{0}\end{array}$} & \multicolumn{2}{|l|}{$\begin{array}{r}\mathrm{NH}_{4}^{+} \\
A\end{array}$} & \multicolumn{2}{|l|}{$\begin{array}{r}\max \\
m_{0}\end{array}$} & \multicolumn{2}{|l|}{$\begin{array}{r}\mathrm{NO}_{3}^{-} \\
C_{0}\end{array}$} & \multicolumn{2}{|l|}{$\begin{array}{r}\mathrm{NO}_{3}^{-} \\
{ }_{A}\end{array}$} & \multicolumn{2}{|l|}{$\begin{array}{r}\max \\
m_{0}\end{array}$} \\
\hline & & & & & & & & & & & & \\
\hline Virolahti & & & & & & & & & & & & \\
\hline Polwet & 0.56 & $(0.09)$ & 0.51 & $(0.10)$ & 2.1 & (1.1) & 0.52 & $(0.07)$ & 0.37 & $(0.07)$ & 1.7 & (1.3) \\
\hline Hainich & 0.38 & $(0.07)$ & 0.27 & $(0.09)$ & 3 & (1.6) & 0.51 & $(0.05)$ & 0.17 & $(0.07)$ & 3 & (2.1) \\
\hline Grillenburg & 0.52 & $(0.07)$ & 0.47 & $(0.09)$ & 2.3 & (1.0) & 0.49 & $(0.05)$ & 0.35 & $(0.05)$ & 1.7 & (1.0) \\
\hline Wetzstein & 0.54 & $(0.07)$ & 0.23 & $(0.07)$ & 2.8 & (2.4) & & & & & & \\
\hline Vielsalm & 0.26 & $(0.06)$ & 0.18 & $(0.08)$ & 3 & (1.9) & & & & & & \\
\hline Oensingen & 0.53 & $(0.10)$ & 0.19 & $(0.09)$ & 5.6 & (2.7) & 0.26 & $(0.05)$ & 0.14 & $(0.05)$ & 5.1 & (1.7) \\
\hline Lägeren & & & & & & & 0.31 & $(0.04)$ & 0.23 & $(0.05)$ & 2.4 & (1.0) \\
\hline Fontainebleau & & & & & & & & & & & & \\
\hline Puéchabon & & & & & & & & & & & & \\
\hline Le Bray & & & & & & & & & & & & \\
\hline San Rossore & & & & & & & & & & & & \\
\hline Roccarespampani & & & & & & & & & & & & \\
\hline Rotterdam & 0.89 & $(0.09)$ & 0.62 & $(0.12)$ & 4.6 & $(0.6)$ & 0.47 & $(0.04)$ & 0.25 & $(0.05)$ & 4.5 & $(0.7)$ \\
\hline Speulderveld & 0.96 & $(0.06)$ & 0.45 & $(0.07)$ & 4.6 & $(0.6)$ & 0.47 & $(0.02)$ & 0.19 & $(0.03)$ & 4.3 & $(0.6)$ \\
\hline Vredepeel & 1.28 & $(0.08)$ & 0.45 & $(0.11)$ & 4.4 & $(0.8)$ & & & & & & \\
\hline Wieringerwerf & 0.81 & $(0.07)$ & 0.49 & $(0.09)$ & 4.8 & $(0.6)$ & 0.47 & $(0.03)$ & 0.18 & $(0.04)$ & 4.3 & $(0.7)$ \\
\hline
\end{tabular}

Table 4. Correlations of WSON deposition with $\mathrm{NH}_{4}^{+}$and $\mathrm{NO}_{3}^{-}$deposition over time within individual sites, as Spearman rank correlation coefficient $(\rho)$ with associated significance probability (GenStat13, VSN International Ltd). Only significant $(p<0.05)$ correlations are shown.

\begin{tabular}{lll}
\hline Site & WSON vs. $\mathrm{NH}_{4}^{+}$ & WSON vs. $\mathrm{NO}_{3}^{-}$ \\
\hline San Rossore & $-0.52(0.004)$ & $-0.44(0.011)$ \\
Vielsalm & $-0.68(0.006)$ & $-0.66(0.007)$ \\
Lägeren & $+0.51(0.002)$ & \\
Pallas & $+0.69(<0.001)$ & $+0.73(<0.001)$ \\
\hline
\end{tabular}

difference. A second check was direct comparison of total N (measured by RIVM using persulphate oxidation) for samples from the Dutch sites with total N (measured by $\mathrm{CEH}$ using high-temperature combustion and chemiluminescence) on the same samples. Orthogonal regression of data from these two independent analyses shows a small negative bias of the persulphate data compared with chemiluminescence, with slope (RIVM : CEH) $=0.95( \pm 0.03$ s.e. $)$ and intercept $(\mathrm{RIVM}-\mathrm{CEH})=-0.12( \pm 0.04$ s.e. $) \mathrm{mg} \mathrm{N}^{-1}$, consistent with the observation that chemiluminescence is slightly more effective (at least for rain samples) in measuring total $\mathrm{N}$ than persulphate digestion (Cape et al., 2001). However, these small differences do not account for the occasional large discrepancy between total $\mathrm{N}$ measurement and prior inorganic $\mathrm{N}$ analyses. The addition of thymol has been shown to be effective as a biocide in rain samples (Cape et al., 2001; Ayers et al., 1998; Hadi and Cape, 1995), so it is unlikely that there would have been large biotic changes in sample composition during shipping. There remains the possibility of abiotic losses caused by chemical reactions during shipping. In some cases, the $\mathrm{pH}$ and $\mathrm{NH}_{4}^{+}$concentrations measured in the laboratory would, at equilibrium at $20^{\circ} \mathrm{C}$, imply transfer of $\mathrm{NH}_{3}$ to the gas phase, which could have been lost from the vial when sampled. Although weak, there was a correlation between the WSON deficit and $\mathrm{NH}_{4}^{+}$concentration, i.e. samples with higher initial $\mathrm{NH}_{4}^{+}$concentrations were more likely to show a lower total $\mathrm{N}$ concentration than the sum of $\mathrm{NH}_{4}^{+}$and $\mathrm{NO}_{3}^{-}$(negative WSON), implying loss of $\mathrm{NH}_{3}$ from the vial. It is possible that at some sites, inclusion of sub-micron particles of minerals could have increased the $\mathrm{pH}$ during transit and led to losses of $\mathrm{NH}_{3}$. Although a small proportion of the overall samples, these anomalies suggest that at some sites the concentration of WSON may have been underestimated; any losses of $\mathrm{N}$ from the sample between the ion analyses and the analysis for total $\mathrm{N}$ would lead to a low value for the calculated WSON.

The second artefact applies only to the samples from the Netherlands. We have already shown good agreement for total $\mathrm{N}$ measured by the RIVM and $\mathrm{CEH}$ laboratories, but for these samples the $\mathrm{NH}_{4}^{+}$concentrations were measured colorimetrically rather than by ion chromatography. It has been shown that amines and amino acids produce positive artefacts in the indophenol blue method for measuring 
ammonium (Cape et al., 2001). Consequently, the reported " $\mathrm{NH}_{4}^{+}$" concentrations are likely to be overestimates of the true $\mathrm{NH}_{4}^{+}$concentrations, leading to a systematic underestimate of WSON concentrations at the 4 Dutch sites.

As seen from Table 1, some of the (non-NitroEurope) sites used wet-only rather than bulk samplers. While this is likely to have led to a lower relative measurement of concentration and deposition, because of additional dry deposition of gases and particles on the bulk collector surfaces, the effect on the proportion of WSON is not known. In the only study to have investigated the potential bias (González Benítez et al., 2009), the difference between wet-only and bulk samplers was up to $50 \%$, but with no clear indication of a difference in the proportion of WSON. Consequently, the overall deposition data for the "wet-only" sites may be biased low relative to the other sites studied.

\subsection{Comparison with the literature}

Comparison of precipitation chemistry data from studies with very different sampling and analytical methods is not straightforward, particularly where the analyte of interest (WSON) is determined by difference, and where contamination and sampling artefacts are handled differently in different studies (Cape et al., 2011). Nevertheless, the present study does need to be set in context. In terms of the inorganic $\mathrm{N}$ component, the annual average concentrations across $\mathrm{Eu}-$ rope show a similar range and geographical pattern to those measured in the EMEP Network (www.emep.int), as shown in Fig. 1. The largest concentrations are seen in central and western Europe, with smaller values to the north and south. By contrast, concentrations of WSON show a smaller range and a less clear geographical pattern (Table 2a). The concentration of WSON as a proportion of total $\mathrm{N}$ in this study ranges from a few $\%$ up to almost $40 \%$. This range is similar to that observed in the UK, between 20 and $50 \%$ (Cape et al., 2004; González Benítez et al., 2009; Vanguelova et al., 2010). Other recent European studies have shown up to $15 \%$ at the Belgian coast (Bencs et al., 2009) and 30\% in Flanders, Belgium (Sleutel et al., 2009), $23 \%$ in the Czech Republic (Kopacek et al., 1997), $38 \%$ in Poland (Kram, 2008), between $17 \%$ and $23 \%$ in the eastern Mediterranean (Mace et al., 2003; Violaki et al., 2010), $8 \%$ in Germany (Michalzik and Matzner, 1999) and between $14 \%$ and $41 \%$ in Finland (Mustajarvi et al., 2008; Piirainen et al., 1998). The available data are shown in Fig. 5, which suggests that the contribution of WSON to total $\mathrm{N}$ in precipitation is greatest to the north and west of Europe, and least in central Europe. However, because the studies cited have all used different methods of sampling and analysis, over different integrating periods and times, such direct comparisons are indicative at best, and may be misleading. For reviews of global and historical data sets see Cornell (2011); Cornell et al. (2003); and Neff et al. (2002).

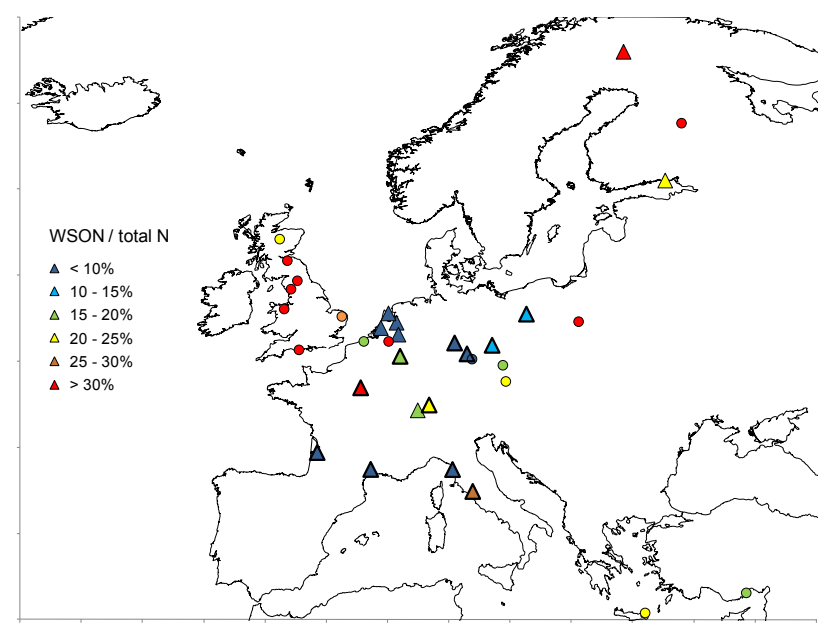

Fig. 5. WSON as \% of total wet-deposited $\mathrm{N}$ across Europe, showing results from this study (triangles) and literature data (circles; see text for citations). "Level 1" sites from this study are shown with bold symbols.

\section{Conclusions}

This study, despite the obvious drawbacks of its opportunistic nature, has confirmed the importance of WSON as a component of wet deposition across Europe, as illustrated by a growing number of individual studies. However, no clear patterns have emerged as to the likely sources, or rather, the lack of pattern has shown that the contribution of WSON to total $\mathrm{N}$ is not unequivocally linked to either ammonium or nitrate across the continent. The relative contribution of WSON to total $\mathrm{N}$ is greater where total $\mathrm{N}$ concentrations and deposition are smallest, but again, there are no consistent temporal or spatial patterns, reflecting earlier conclusions on the varied sources and chemical composition of WSON (Cape et al., 2011).

However, the study has reinforced the fact that wet deposition of total nitrogen to European ecosystems is systematically underestimated by the use of inorganic $\mathrm{N}$ data alone. Although the bioavailability of WSON may be less than for inorganic $\mathrm{N}$, there is sufficient evidence that at least some components are bioavailable (Liu et al., 2011; Peierls and Paerl, 1997; Wedyan et al., 2007; Krab et al., 2008; GalletBudynek et al., 2009; Nasholm et al., 2009; Xu et al., 2006). In terms of demonstrable effects of deposited N, empirical critical loads for different ecosystems have been defined on the basis of the measured or estimated deposition of inorganic $\mathrm{N}$ alone (UNECE, 2010). If ecosystems respond similarly to deposition of organic $\mathrm{N}$, then the additional deposition should be taken into account, particularly for sensitive ecosystems where deposition is close to the critical load based on inorganic $\mathrm{N}$ alone. Although it could be argued that organic $\mathrm{N}$ deposition is implicitly included in such estimates, where critical loads have been established based on the measured 
responses to inorganic $\mathrm{N}$ deposition in the field, the lack of a clear relationship across Europe between inorganic and organic $\mathrm{N}$ deposition means that some ecosystems may be subject to considerably greater total $\mathrm{N}$ deposition than that estimated from inorganic $\mathrm{N}$ deposition alone, while in other areas the additional deposition of organic $\mathrm{N}$ may be negligible. However, this study has shown that the relative importance of organic $\mathrm{N}$ is greatest where total $\mathrm{N}$ deposition is smallest, i.e. precisely in those areas where sensitive ecosystems are facing pressure from anthropogenic $\mathrm{N}$ deposition. Inclusion of organic $\mathrm{N}$ in the estimation of empirical critical loads would require measurement (ideally) or estimation of the additional wet (and dry) deposition of organic N. Although the need for such measurements is clear, the present study implies that estimating such deposition will be very difficult because of the lack of consistent spatial patterns in WSON, either in absolute amounts or as a fraction of total N. Similarly, where processes such as species change (Stevens et al., 2010) are described or modelled using deposition of inorganic $\mathrm{N}$ as an explanatory variable, the potential role of WSON should not be ignored.

Acknowledgements. The authors gratefully acknowledge financial support from the European Commission 6th Framework Programme for the NitroEurope IP, and from the NERC Centre for Ecology \& Hydrology. JGB also acknowledges support from the School of Chemistry, University of Edinburgh.

Edited by: G. Billen

\section{References}

Ayers, G. P., Fukuzaki, N., Gillett, R. W., Selleck, P. W., Powell, J. C., and Hara, H.: Thymol as a biocide in Japanese rainwater, J. Atmos. Chem., 30, 301-310, 1998.

Bencs, L., Krata, A., Horemans, B., Buczynska, A. J., Dirtu, A. C., Godoi, A. F. L., Godoi, R. H. M., Potgieter-Vermaak, S., and Van Grieken, R.: Atmospheric nitrogen fluxes at the Belgian coast: 2004-2006, Atmos. Environ., 43, 3786-3798, doi:10.1016/j.atmosenv.2009.04.002, 2009.

Cape, J. N., Kirika, A., Rowland, A. P., Wilson, D. R., Jickells, T. D., and Cornell, S.: Organic nitrogen in precipitation: real problem or sampling artefact?, The Scientific World, 1, 230-237, 2001.

Cape, J. N., Anderson, M., Rowland, A. P., and Wilson, D.: Organic nitrogen in precipitation across the United Kingdom, Water Air Soil Poll., Focus, 4, 25-35, 2004.

Cape, J. N., Cornell, S., Jickells, T., and Nemitz, E.: Organic nitrogen in the atmosphere - where does it come from?, Atmos. Res., 102, 30-48, 2011.

Cornell, S. E.: Atmospheric nitrogen deposition: Revisiting the question of the importance of the organic component, Environ. Pollut., 159, 2214-2222, 2011.

Cornell, S. E. and Jickells, T. D.: Water-soluble organic nitrogen in atmospheric aerosol: a comparison of UV and persulfate oxidation methods, Atmos. Environ., 33, 833-840, 1999.
Cornell, S. E., Jickells, T. D., Cape, J. N., Rowland, A. P., and Duce, R. A.: Organic nitrogen deposition on land and coastal environments: a review of methods and data, Atmos. Environ., 37, 2173 2191, 2003.

Dämmgen, U., Erisman, J. W., Cape, J. N., Grünhage, L., and Fowler, D.: Practical considerations for addressing uncertainties in monitoring bulk deposition, Environ. Pollut., 134, 535-548, 2005.

Flechard, C. R., Nemitz, E., Smith, R. I., Fowler, D., Vermeulen, A. T., Bleeker, A., Erisman, J. W., Simpson, D., Zhang, L., Tang, Y. S., and Sutton, M. A.: Dry deposition of reactive nitrogen to European ecosystems: a comparison of inferential models across the NitroEurope network, Atmos. Chem. Phys., 11, 2703-2728, doi:10.5194/acp-11-2703-2011, 2011.

GalletBudynek, A., Brzostek, E., Rodgers, V. L., Talbot, J. M., Hyzy, S., and Finzi, A. C.: Intact amino acid uptake by northern hardwood and conifer trees, Oecologia, 160, 129-138, 2009.

González Benítez, J. M., Cape, J. N., Heal, M. R., van Dijk, N., and Díez, A. V.: Atmospheric nitrogen deposition in south-east Scotland: Quantification of the organic nitrogen fraction in wet, dry and bulk deposition, Atmos. Environ., 43, 4087-4094, 2009.

Hadi, D. A. and Cape, J. N.: Preservation of throughfall samples by chloroform and thymol, Int. J. Environ. An. Ch., 61, 103-116, 1995.

Hjellbrekke, A. G. and Fjaeraa, A. M.: Data Report 2009: Acidifying and eutrophying compounds and particulate matter, EMEPCCC Report 1/2011, NILU, Kjeller, Norway, 139 pp., 2011.

Kieber, R., Long, M., and Willey, J.: Factors influencing nitrogen speciation in coastal rainwater, J. Atmos. Chem., 52, 81-99, 2005.

Kopacek, J., Prochazkova, L., Hejzlar, J., and Blazka, P.: Trends and seasonal patterns of bulk deposition of nutrients in the Czech Republic, Atmos. Environ., 31, 797-808, 1997.

Krab, E. J., Cornelissen, J. H. C., Lang, S. I., and van Logtestijn, R. S. P.: Amino acid uptake among wide-ranging moss species may contribute to their strong position in higher-latitude ecosystems, Plant Soil, 304, 199-208, 2008.

Kram, K. J.: Nitrogen deposition and flux through birch stands (Betula pendula Ens Ehrh.) in the Kampinos National Park (central Poland), Pol. J. Ecol., 56, 605-612, 2008.

Liu, H., Jeong, J., Gray, H., Smith, S., and Sedlak, D. L.: Algal uptake of hydrophobic and hydrophilic dissolved organic nitrogen in effluent from biological nutrient removal municipal wastewater treatment systems, Environ. Sci. Technol., 46, 713-721, doi:10.1021/es203085y, 2011.

Mace, K. A., Kubilay, N., and Duce, R. A.: Organic nitrogen in rain and aerosol in the eastern Mediterranean atmosphere: An association with atmospheric dust, J. Geophys. Res.-Atmos., 108, 4320, doi:10.1029/2002JD002997, 2003.

Michalzik, B. and Matzner, E.: Dynamics of dissolved organic nitrogen and carbon in a Central European Norway spruce ecosystem, Eur. J. Soil Sci., 50, 579-590, 1999.

Mustajarvi, K., Merila, P., Derome, J., Lindroos, A. J., Helmisaari, H. S., Nojd, P., and Ukonmaanaho, L.: Fluxes of dissolved organic and inorganic nitrogen in relation to stand characteristics and latitude in Scots pine and Norway spruce stands in Finland, Boreal Environ. Res., 13, 3-21, 2008.

Nasholm, T., Kielland, K., and Ganeteg, U.: Uptake of organic nitrogen by plants, New Phytol., 182, 31-48, doi:10.1111/j.1469- 
8137.2008.02751.x, 2009.

Neff, J. C., Holland, E. A., Dentener, F. J., McDowell, W. H., and Russell, K. M.: The origin, composition and rates of organic nitrogen deposition: A missing piece of the nitrogen cycle?, Biogeochemistry, 57, 99-136, 2002.

Peierls, B. L. and Paerl, H. W.: Bioavailability of atmospheric organic nitrogen deposition to coastal phytoplankton, Limnol. Oceanogr., 42, 1819-1823, 1997.

Piirainen, S., Finer, L., and Starr, M.: Canopy and soil retention of nitrogen deposition in a mixed boreal forest in eastern Finland, Water Air Soil Poll., 105, 165-174, 1998.

Skiba, U., Drewer, J., Tang, Y. S., van Dijk, N., Helfter, C., Nemitz, E., Famulari, D., Cape, J. N., Jones, S. K., Twigg, M., Pihlatie, M., Vesala, T., Larsen, K. S., Carter, M. S., Ambus, P., Ibrom, A., Beier, C., Hensen, A., Frumau, A., Erisman, J. W., Brüggemann, N., Gasche, R., Butterbach-Bahl, K., Neftel, A., Spirig, C., Horvath, L., Freibauer, A., Cellier, P., Laville, P., Loubet, B., Magliulo, E., Bertolini, T., Seufert, G., Andersson, M., Manca, G., Laurila, T., Aurela, M., Lohila, A., ZechmeisterBoltenstern, S., Kitzler, B., Schaufler, G., Siemens, J., Kindler, R., Flechard, C., and Sutton, M. A.: Biosphere-atmosphere exchange of reactive nitrogen and greenhouse gases at the NitroEurope core flux measurement sites: Measurement strategy and first data sets, Agr. Ecosyst. Environ., 133, 139-149, 2009.

Sleutel, S., Vandenbruwane, J., De Schrijver, A., Wuyts, K., Moeskops, B., Verheyen, K., and De Neve, S.: Patterns of dissolved organic carbon and nitrogen fluxes in deciduous and coniferous forests under historic high nitrogen deposition, Biogeosciences, 6, 2743-2758, doi:10.5194/bg-6-2743-2009, 2009.

Stevens, C. J., Duprè, C., Dorland, E., Gaudnik, C., Gowing, D. J. G., Bleeker, A., Diekmann, M., Alard, D., Bobbink, R., Fowler, D., Corcket, E., Mountford, J. O., Vandvik, V., Aarrestad, P. A., Muller, S., and Dise, N. B.: Nitrogen deposition threatens species richness of grasslands across Europe, Environ. Pollut., 158, 2940-2945, 2010.
Tang, Y. S., Simmons, I., van Dijk, N., Di Marco, C., Nemitz, E., Dämmgen, U., Gilke, K., Djuricic, V., Vidic, S., Gliha, Z., Borovecki, D., Mitosinkova, M., Hanssen, J. E., Uggerud, T. H., Sanz, M. J., Sanz, P., Chorda, J. V., Flechard, C. R., Fauvel, Y., Ferm, M., Perrino, C., and Sutton, M. A.: European scale application of atmospheric reactive nitrogen measurements in a low-cost approach to infer dry deposition fluxes, Agriculture, Ecosyst. Environ., 133, 183-195, 2009.

UNECE: Empirical critical loads and dose-response relationships, UNECE Working Group on Effects, ECE/EB.AIR/WG.1/2010/14, 8, 2010.

Vanguelova, E. I., Benham, S., Pitman, R., Moffat, A. J., Broadmeadow, M., Nisbet, T., Durrant, D., Barsoum, N., Wilkinson, M., Bochereau, F., Hutchings, T., Broadmeadow, S., Crow, P., Taylor, P., and Houston, T. D.: Chemical fluxes in time through forest ecosystems in the UK - Soil response to pollution recovery, Environ. Pollut., 158, 1857-1869, doi:10.1016/j.envpol.2009.10.044, 2010.

Violaki, K., Zarbas, P., and Mihalopoulos, N.: Long-term measurements of dissolved organic nitrogen (DON) in atmospheric deposition in the Eastern Mediterranean: Fluxes, origin and biogeochemical implications, Mar. Chem., 120, 179-186, doi:10.1016/j.marchem.2009.08.004, 2010.

Wedyan, M. A., Fandi, K. G., and Al-Rousan, S.: Bioavailability of atmospheric dissolved organic nitrogen in the marine aerosol over the Gulf of Aqaba, Aust. J. Basic Appl. Sci., 1, 208-212, 2007.

Xu, X., Ouyang, H., Kuzyakov, Y., Richter, A., and Wanek, W.: Significance of organic nitrogen acquisition for dominant plant species in an alpine meadow on the Tibet plateau, China, Plant Soil, 285, 221-231, 2006. 